\title{
Biology of a scale-independent predator-prey interaction
}

\author{
Richard B. Aronson \\ Institute of Marine and Coastal Sciences, Rutgers University, New Brunswick, New Jersey 08903, USA
}

\begin{abstract}
Dense populations of epifaunal, suspension-feeding ophiuroids, or brittlestar beds, are widely distributed geographically, but they are rare and are restricted in their habitat distribution. On a microecological scale (meters to kilometers, hours to days), experimental studies and censuses of sublethal injury show the distribution of brittlestar beds in the British Isles and the Bahamas to be limited by predatory fishes and crabs. On an ecological scale (tens to hundreds of $\mathrm{km}$, decades to centuries), there is evidence that predation by seastars limits the distribution of brittlestar beds in the English Channel, beyond the stringent restrictions imposed by fish and crab predators in modern ecosystems. On an evolutionary scale (globally, millions to tens of millions of years), the Mesozoic decline of brittlestar beds visible in the fossil record is associated with the diversification of predators adapted to eat skeletonized prey, including teleostean fishes, neoselachian sharks, and decapod crustaceans. In this biological interaction, microecological- and ecological-scale processes are reflected in evolutionaryscale patterns. The scale-independent effects of predation on brittlestar beds, and other scaleindependent biological interactions, may be related to self-organized criticality, a consequence of the non-linear dynamics of the biosphere.
\end{abstract}

\section{INTRODUCTION}

Scale is important in ecology and evolution (Allen \& Starr 1982, Gingerich 1983, Steele 1985, O'Neill et al. 1986, Frost et al. 1988, Eldredge 1989, Menge \& Olson 1990, Jackson 1991, Pimm 1991, Cracraft 1992). Variables such as abundance and diversity often behave unpredictably at one level of resolution but produce predictable patterns at another (e.g. Sale 1980, Sutherland 1981, Sollins et al. 1983, Victor 1986, Powell 1989, Wiens 1989, Bailey 1990, Carpenter \& Leavitt 1991). For example, the physical events that cause mass extinctions disrupt evolutionary trajectories because organisms cannot adapt to phenomena that occur so intensely and so infrequently (Gould 1985, Jablonski 1986).

Yet biological processes can act in similar ways on different spatiotemporal scales. The antipredator morphologies of gastropods show equivalent trends on local and biogeographic scales (e.g. Vermeij 1978, Seeley 1986, Appleton \& Palmer 1988, West et al. 1991). Herbivores have similar ecological and evolutionary effects on marine algae (Steneck 1983).
Replacement of bryozoan functional grades over evolutionary time has been interpreted in terms of the competitive abilities of individual colonies (Lidgard 1986, Lidgard \& Jackson 1989). Bioturbators may also produce analogous effects on ecological and evolutionary scales (Thayer 1983).

The effects of functionally new predators on marine food webs occur in a similar geographic pattern on different temporal scales (Aronson 1990). Adding trophic levels over evolutionary time - the appearance of new, skeleton-crushing (durophagous) predators as part of the so-called Mesozoic marine revolution (Vermeij 1977 ) - produced cascading effects in nearshore communities. These community changes, which included the elimination of stalked crinoids and other epifaunal suspension-feeders from soft-substratum habitats, spread to offshore environments with the offshore expansion of novel predatory taxa (Meyer \& Macurda 1977, Vermeij 1977, 1987, Bottjer \& Jablonski 1988). The superposition of yet another level of predation in historical times - human fishing pressure over the past few centuries - is likewise producing cascading community effects onshore and then progressively further 
offshore (Aronson 1990). Hay (1984) observed an onshore-offshore gradient in the effects of fishing on an even smaller scale, within individual coral reefs.

This review tests the hypothesis that predation and physical disturbance have analogous effects on dense ophiuroid populations on 3 scales of observation (Table 1). The intent is not to argue the primacy of one

Table 1 Scales on which the trophic relationship was studied

\begin{tabular}{|c|c|c|}
\hline \multirow[t]{2}{*}{ Scale } & \multicolumn{2}{|c|}{ Magnitude } \\
\hline & Time & Space \\
\hline Microecological & Hours to days & Meters to kilometers \\
\hline Ecological & $\begin{array}{l}\text { Decades to } \\
\text { centuries }\end{array}$ & $\begin{array}{l}\text { Tens to hundreds } \\
\text { of } \mathrm{km}\end{array}$ \\
\hline Evolutionary & $\begin{array}{l}\text { Millions to } \\
\text { tens of millions } \\
\text { of years }\end{array}$ & Global \\
\hline
\end{tabular}

causal agent, predation, over another, physical disturbance. Rather, my objectives are to demonstrate that this trophic linkage behaves in similar ways under analogous circumstances on different scales and to propose an explanation - self-organized criticality - for the observed scale-independence. The names chosen for the 3 scales are intended primarily as a linguistic convenience, not as an a priori statement about differences in process on those scales

\section{SELF-ORGANIZED CRITICALITY}

Fractals are geometrical entities that have a similar, though not necessarily identical, appearance at all scales of resolution (see Palmer 1992 on definitions of the term 'fractal'). Many natural objects are fractals (Mandelbrot 1983, 1989, Gleick 1987), and Sugihara \& May (1990) reviewed the robust analogy between geometrical fractals and the fractal scaling of population trajectories. While the pervasiveness of fractals in nature has not been completely explained, there is an established link between fractals and the chaotic (highly complex and disordered, yet determinate) behavior of large, interactive systems (Gleick 1987, Mandelbrot 1989, Flam 1991)

Certain large, interactive systems exhibit selforganized criticality rather than fully chaotic behavior (Allen 1985, Bak \& Chen 1989, 1991, Kauffman 1991). Complex causal chains bring such systems to critical states at which further perturbations, large or small, cause sudden changes. Subsequent events produce successive critical states and more changes. The changes vary in magnitude, and the temporal spec- trum of those changes is 'weakly chaotic': the fluctuations are more predictable and less sensitive to minor perturbation than in fully chaotic systems (Bak \& Chen 1991, Kauffman 1991). Systems exhibiting selforganized criticality have 2 hallmarks. First, the sudden changes show fractal scaling. Second, the magnitude of a sudden change varies as the inverse of its frequency; this is called 'flicker noise', or ' $1 / \mathrm{f}$ noise'. Flicker noise is equivalent to 'reddened spectra' (Steele 1985, Pimm 1991).

Bak \& Chen (1989, 1991) used the example of a sandpile to illustrate self-organized criticality. Adding individual sand grains to the pile eventually results in a threshold state. The next sand grain added produces an avalanche within the sandpile. Repeated additions produce more critical states and more avalanches, of different sizes. The spatial arrangement of the avalanches is fractal, and there are proportionately more small avalanches than large ones. I argue that the relationships between ophiuroids and their predators can be interpreted in a similar way.

The theory of self-organized criticality may explain the apparent fractal geometries of sandpiles, earthquakes, and landscape topographic contours. However, in the real world, the model holds only within a specific range of scales in each of these cases: outside that range, self-organized criticality and its accompanying fractal geometry break down, so that the observed physical arrangement is not infinitely scaleinvariant (Mehta \& Barker 1991, Montgomery \& Dietrich 1992). The scale-independence of biological interactions also has limits.

\section{MICROECOLOGY OF LIVING BRITTLESTAR BEDS}

\section{British Isles}

Epifaunal, suspension-feeding ophiuroids form dense aggregations, or 'brittlestar beds', in shallow water in a number of locations throughout the world, although they are best known from northern Europe (Warner 1971, Holme 1984, Aronson 1989a, Hily 1991). In the British Isles, essentially monospecific stands of the ophiuroids Ophiothrix fragilis (Abildgaard) and Ophiocomina nigra (Abildgaard) are widely distributed, though uncommon. Population densities range from hundreds to thousands of individuals per $\mathrm{m}^{2}$. Ophiuroids are by far the numerically dominant suspension-feeders in these communities; in some areas the sea floor is completely obscured by ophiuroids. Brittlestar beds occur on a variety of substrata, ranging from sandy silt with shelly material, to pebble, to hard bottom. They are found commonly on level, unconsoli- 
dated bottoms containing shell, pebble, or cobble (Aronson 1989a, Hily 1991). Ophiuroids are generally rare in rocky reefs, and they shelter in crevices and under rubble. In many cases, brittlestar beds are separated from rocky reefs along the shore by an ophiuroid-free 'halo' zone on the level bottom, several meters wide. The brittlestar beds begin abruptly at the seaward edges of the halos.

Although Ophiothrix fragilis and Ophiocomina nigra populations are catholic in their utilization of substratum, they do have 2 important physical requirements. First, these brittlestar beds generally are found in current-swept areas. Strong currents are necessary to supply enough suspended matter to meet the energetic needs of the enormous number of individuals (Warner 1971, Warner \& Woodley 1975, Hily et al. 1988). Second, dense populations do not persist in areas of excessive sedimentation, because too much sediment fouls the brittlestars' feeding apparatus (arm spines, tube feet, and mucous strands) and ultimately suffocates them (Schäfer 1962).

A third requirement for the persistence of British brittlestar beds is low predation intensity. I define 2 aspects of predation intensity (Aronson 1989a). Predation potential is the propensity of the predators in a habitat to consume prey, given the species composition of the predator guild, predator abundance and food preferences, and the availability of alternative food resources. Predation pressure is the frequency of predatory attacks on prey.

Predation potential is low in brittlestar beds, and high on or adjacent to rocky reefs. Tethering techniques (Aronson 1987, 1989a) were used to measure predation potential in an Ophiothrix fragilis bed off the Isle of Man. The mortality of tethered $O$. fragilis was significantly higher in both daytime and nighttime experiments on the sand bottom at the base of a nearby rocky reef than in the brittlestar bed. Experiments at Millport, Great Cumbrae Island, Scotland produced similar results: the mortality of tethered Ophiocomina nigra was low in an $O$. nigra bed but high on a nearby rocky reef (Fig. 1). Fishes of the wrasse family (Labridae), the swimming crab Nicora (= Liocarcinus) puber (Linnaeus) (Portunidae), and the forcipulate seastar Asterias rubens Linnaeus ate the tethered ophiuroids.

Predators attacked almost 4 times as many tethered ophiuroids in the rocky reef habitats as they did in the 2 brittlestar beds. Fish and crabs were responsible for more than $75 \%$ of the attacks in the rocky reef experiments; the relatively slow-moving Asterias rubens accounted for more than $75 \%$ of the few attacks in the brittlestar beds (Fig. 2). Fish and crabs were common on the rocky reefs and uncommon or rare in the brittlestar beds. The abundance of $A$. rubens did not

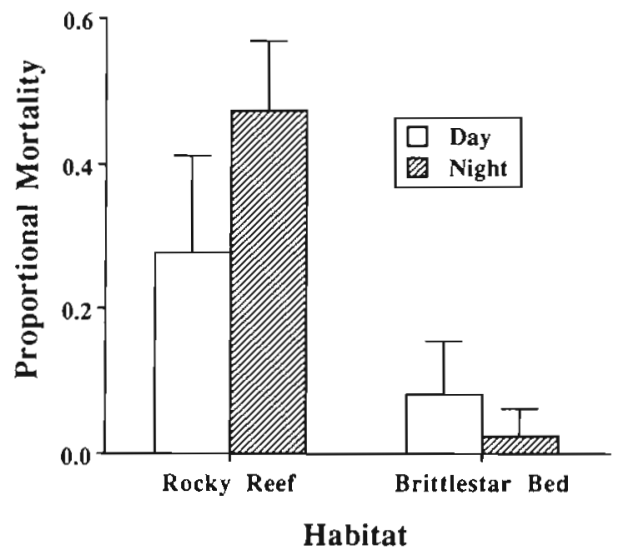

Fig. 1. Ophiocomina nigra. Mean daytime $(n=5)$ and nighttime $(n=3)$ mortality $(+S D)$ of tethered individuals in a rocky reef and a nearby $O$. nigra bed at Great Cumbrae Island, west coast of Scotland. Predation potential was significantly higher in the rocky reef both during the day $(p<0.02)$ and at night $(\mathrm{p}<0.01 ; t$-tests on arcsine-transformed proportions). Data are from Aronson (1989a)

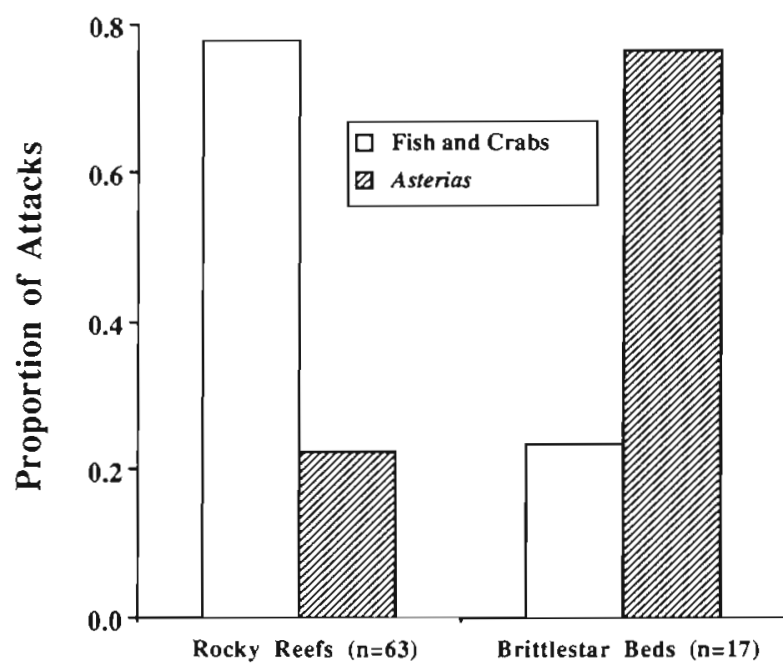

Community Type

Fig. 2. Ophiothrix fragilis and Ophiocomina nigra. Breakdown of attacks on tethered ophiuroids by predator functional group in experiments at the Isle of Man and Great Cumbrae Island, west coast of Scotland. Data are from Aronson (1989a)

correlate with habitat or with the number of tethered ophiuroids attacked.

The width of the halo probably represents the distance predatory wrasses and crabs will range from their shelters in the reef to forage on the level bottom. Wrasses and Nicora puber appear to be constrained when foraging in open habitats by the current or historical activity of their own predators (e.g. the Atlantic cod Gadus morhua Linnaeus). 


\section{Bahamas}

An analogous situation exists in the Caribbean. A dense ophiuroid population in Sweetings Pond, an isolated saltwater lake on Eleuthera Island in the Bahamas (mean density $>250$ ind. $\mathrm{m}^{-2}$ in 1982-83), consisted almost entirely of Ophiothrix oerstedi Lütken (Aronson \& Harms 1985). Predatory reef fish were absent, and the top carnivores were octopuses, which do not eat brittlestars. Ophiuroids are cryptic and much less abundant in coastal reef and lagoonal habitats of the Caribbean, where fish, their primary predators, are abundant. Ophiothrix oerstedi, transplanted to the Eleuthera coast and allowed to move freely within uncovered arenas at densities comparable to Sweetings Pond, were all consumed by fish within 48 h. No significant mortality occurred in meshcovered, fish exclusion arenas at the coastal site; in uncovered arenas in Sweetings Pond; or in covered arenas in Sweetings Pond. The only predators of $O$. oersted $i$ in the lake were, again, slow-moving invertebrates: a polychaete worm and a predatory ophiuroid. The population density of $O$. oerstedi within Sweetings Pond was limited by the rugosity of the substratum: rougher, more heterogeneous microhabitats supported more brittlestars. Tethering experiments with 0 . oerstedi in Sweetings Pond showed predation potential to be very low compared to coastal back reef habitats in Belize; St. Croix and St. John, U.S. Virgin Islands; Barbados; and the Eleuthera coast (Aronson 1987, in press).

\section{Sublethal injury in ophiuroids: predation versus storm damage}

Sublethal arm damage, the proportion of individuals regenerating 1 or more arms, provides an index of predation pressure on Caribbean shallow-water ophiuroids. Consistent with the measurements of predation potential, $38 \%$ of Ophiothrix oerstedi in Sweetings Pond had regenerating arms, whereas 73 to $80 \%$ were regenerating in the back reef habitats in Belize and St. John (Aronson 1987). Assessing predation pressure based on injury frequencies can be difficult due to the potential problem of predator efficiency: low levels of injury will accompany high predation potentials when most of the attacks are lethal. However, low injury levels in ophiuroid populations do in fact indicate low predation pressure (see below).

Beyond the problem of predator efficiency, the relationship of population injury patterns to predation potential may be confounded by physical damage from storms: rubble movement during hurricanes could cause arm injuries. Sweetings Pond, however, is protected from storm effects by the high limestone ridge that isolates it from the coast of Eleuthera. In a similar fashion, 2 coastal back reef communities in the Caribbean were protected by their reef crests from hurricane damage. Rubble movement was minor at back reef sites in Jamaica and St. Croix during Hurricanes Gilbert (1988) and Hugo (1989) respectively. The proportion of injured Ophiothrix oerstedi did not increase in association with these hurricanes (Aronson 1991b, in press). Woodley et al. (1981) mention increased damage to Jamaican ophiuroids after Hurricane Allen in 1980.

An average of $36 \%$ of individuals in 5 British brittlestar beds were regenerating arms (Aronson 1989a). The very high injury level (92\%) for Ophiothrix fragilis in the one rocky reef sampled may reflect high predation pressure, heavy storm damage, or both, whereas the low values for the brittlestar beds suggest that predators and storms caused few injuries [see Alva \& Jangoux (1990) on storm damage to ophiuroids in the rocky intertidal].

\section{PERSISTENCE ON AN ECOLOGICAL SCALE}

The ophiuroid-dominated community of Sweetings Pond has persisted since at least the early 1970s. The biota in 1972 was qualitatively the same as in 1982-83 (Aronson \& Harms 1985), 1986 (Aronson 1987), and 1988 (R. Aronson pers. obs.). The British brittlestar beds are also long-lived communities. The populations in Scotland and the Isle of Man have persisted continuously for the past several decades at least. There is even a record of the Isle of Man Ophiothrix fragilis bed from more than a century ago (Chadwick 1886).

The seastars Luidia ciliaris (Philippi) and L. sarsi Düben \& Koren are voracious predators of ophiuroids and other echinoderms (Fenchel 1965, Brun 1972). Records of Ophiothrix fragilis abundance in the western English Channel, spanning the past century, show a negative association with the abundance of $L$. ciliaris (Holme 1984; summarized in Fig. 3). Holme (1984) suggested that a phenomenal increase in Luidia spp. abundance after 1968 reduced the abundance of $O$. fragilis in the western Channel. During the 1970 s and early 1980s, populations of $O$. fragilis persisted in the southern and eastern parts of the Channel, where Luidia spp. remained absent. Predator and prey abundance also were inversely related in the western Channel during the period 1895-98. The mean abundances of $O$. fragilis for this interval and for the intervals 1957-67, 1968-75, and 1976-81 are based on sample sizes ranging from 10 to 19 stations. In contrast, 


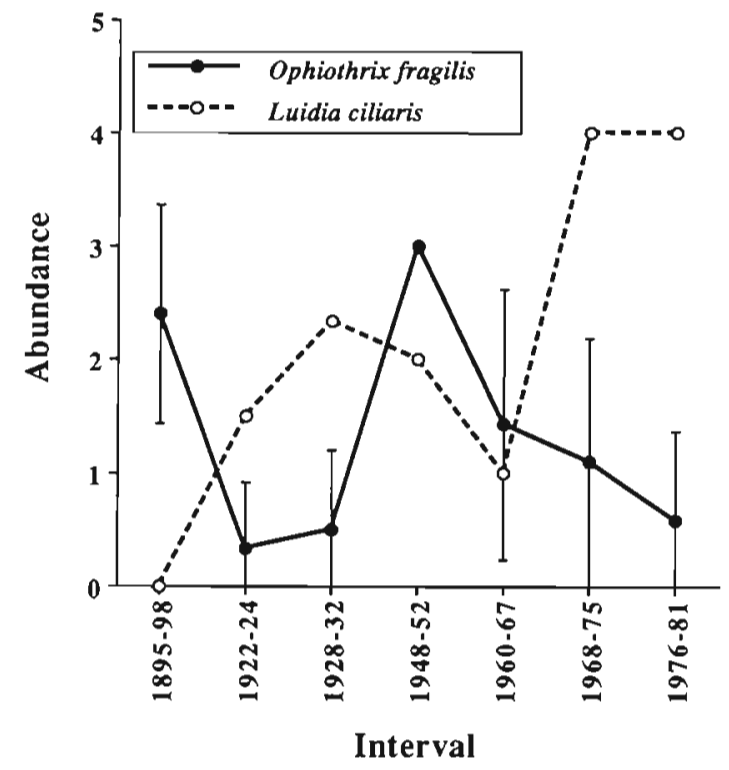

Fig. 3. Ophiothrix fragilis and Luidia ciliaris. Abundance relationship in the western English Channel since the end of the last century, based on data compiled by Holme (1984). Within each time interval, the average abundance index for $O$. fragilis was calculated for each station from Table 3 in Holme (1984). The mean ( \pm SD) of the station averages is plotted. Ophiothrix fragilis abundance indices: 0 : absent; 1 : rare $\left(<1\right.$ ind $\left.\mathrm{m}^{-2}\right) ; 2$ : occasional $\left(1-10\right.$ ind. $\left.\mathrm{m}^{-2}\right)$; 3: common $\left(>10\right.$ ind $\mathrm{m}^{-2}$ ). Luidia ciliaris indices are summaries of qualitative abundance data (Table 3 in Holme 1984): 0: absent; 1: rare or occasional; 2 : uncommon; 3 : present; 4 : common or frequent

the $O$. fragilis abundance data for 1922-23, 1928-32, and $1948-52$ are based on only 2 to 4 stations per interval, so it is difficult to draw conclusions for 1922-52.

Draper (1967) considered wave-induced oscillatory bottom currents in typical years to be uniform in the English Channel from its westernmost extent $\left(3^{\circ} \mathrm{W}\right)$ eastward to the point where it narrows at the Cotentin Peninsula, France $\left(2^{\circ} \mathrm{W}\right)$. This expanse includes the area over which Holme (1984) noticed the negative Ophiothrix-Luidia relationship. It also includes areas to the east along the south coast of England, which populations of Luidia spp. did not reach and in which brittlestar beds persisted after the late 1960s. The disappearance of $O$. fragilis beds therefore cannot be explained by the geographic distribution of bottom currents due to normal ocean swells and storm waves.

Winter storms occur every year in the British Isles. Such storms can severely depress the survivorship of benthic invertebrates that recruited the previous summer (Duineveld et al. 1991). However, storms are too frequent to limit beds that persist for decades, and they are too frequent to drive the multidecadal cycle of ophiuroid abundance that Holme (1984) observed in the western Channel. It is conceivable that lowfrequency $\left(<1\right.$ decade $^{-1}$ ), high-intensity storms scatter individual brittlestar beds. It is difficult to imagine how even a very severe storm could affect ophiuroid populations over an entire region such as the western English Channel. There is no evidence of such a catastrophic event in the late 1960 s, nor is there any indication that gale force winds increased in the western Channel at that time (Anonymous 1960-75).

The large increase in abundance of Luidia spp. and the decline of Ophiothrix fragilis in the late 1960s may have been related to the Russell Cycle, a multidecadal oceanographic cycle in the western Channel (Southward 1980, Holme 1984). Sea temperature increased, and significant changes occurred in circulation patterns, nutrient levels, plankton composition, and the pelagic ichthyofauna after the 1920s. These changes persisted from 1930 through the early 1960s, after which they largely reversed.

Causal relations among the changes and reversals are far from clear (Southward 1980). It is known that Luidia spp. larvae were more common in the post1968 plankton than in plankton from the opposite phase of the cycle (Holme 1984). Extremely cold water can kill the infaunal ophiuroid Amphiura filiformis (O. F. Müller) (Muus 1981); however, the sea temperature decline of the early 1960 s occurred several years before populations of Luidia spp. increased and Ophiothrix fragilis declined. By 1968, sea temperature in the western Channel had begun to rise again (Southward 1980), eliminating a direct role for temperature. Whatever the ultimate oceanographic causality, the proximate cause of the late 1960 s decline in $O$. fragilis appears to have been predation by Luidia spp., although increasing predation by haddock, Gadus aeglifinus (Linnaeus), at that time may also have played a role (Holme 1984).

Hurricanes Gilbert and Hugo were among the strongest recorded in the Caribbean this century. Despite the energy of their associated storm waves, they had no effect on ophiuroid abundance or predator-prey relations in back reef habitats in Jamaica and St. Croix (Aronson 1991b, in press).

\section{EVOLUTIONARY-SCALE COMMUNITY CHANGE}

Modern epifaunal, suspension-feeding brittlestar beds live in habitats where they experience low levels of predation intensity. Dense assemblages of fossil ophiuroids from shallow, marine, soft-sediment environments range from the Ordovician (the time of first appearance of the Ophiuroidea) through the 
Pleistocene (Table 2). Interpreting these assemblages as representing dense populations of epifaunal suspension-feeders requires both functional and taphonomic analyses of the ophiuroids.

It is difficult to deduce the life habits of ophiuroids from their morphology, but some generalizations are possible. Ophiothrix spp., Ophiocomina nigra, and most other shallow-water ophiuroids employ several feeding modes, including both suspension-feeding and deposit-feeding (Warner 1982). Ophiuroids that burrow deeply into the sediment have long, thin, fragile arms compared to most epifaunal species. The arms of the fossil ophiuroids under consideration are not especially long, suggesting that they lived either on top of or slightly below the sediment. Like living Ophiothrix spp. and Ophiocomina nigra beds, these were epifaunal dense populations, which probably derived some proportion of their energy from suspension-feeding.

Rosenkranz (1971). Goldring \& Stephenson (1972), and Aronson \& Sues (1987) reviewed the sedimentology and taphonomy of fossil assemblages that represent dense ophiuroid populations. Ophiuroids disarticulate soon after death (Schäfer 1962), so preservation of dense populations generally requires rapid burial by catastrophic sedimentation events. The ophiuroids in the assemblages listed in Table 2 were either preserved in life position (autochthonous assemblages), or they were transported only short distances prior to burial and preservation (hypoautochthonous assemblages). When these populations were alive, their densities varied from ca 50 to several thousand ind. $\mathrm{m}^{-2}$ (Kesling \& Le Vasseur 1971, Caviglia 1976, Aronson \& Sues 1987). Other fossil dense assemblages represent the results of significant post-mortem transport (Goldring \& Stephenson 1972); these allochthonous assemblages are not included in Table 2 .

\section{Patterns of sublethal injury in fossil brittlestar beds}

Predators such as fish and crustaceans have a low preservation potential (Schäfer 1962). Therefore, the prospects are rather bleak for quantifying predation intensity by censusing predators in fossil assemblages. A better, though less direct method is to use the frequency of sublethal damage to the ophiuroids as a predation index.

Data on the frequency of sublethal arm injuries are available for 9 well-preserved fossil brittlestar beds: 3 from the Paleozoic, 3 from the Mesozoic, and 3 from the Cenozoic. In all cases, the proportion of individuals regenerating 1 or more arms is less than $2 \%$ (Table 3 ). The obvious explanation is that the frequency of predator-prey encounters, the frequency of lethal pre-
Table 2. Records of fossil dense, autochthonous, shallowwater brittlestar beds (expanded from Aronson 1989b)

\begin{tabular}{|c|c|c|}
\hline Age & Locality & Source \\
\hline Late Pleistocene & Dunbar, Scotland & Aliman (1863) \\
\hline Mid-Pleistocene & $\begin{array}{l}\text { Chiba Prefecture, } \\
\text { Japan }\end{array}$ & This study \\
\hline Late Miocene & $\begin{array}{l}\text { Southern California, } \\
\text { USA }\end{array}$ & Merriam (1931) \\
\hline $\begin{array}{l}\text { Early to Mid- } \\
\text { Miocene }\end{array}$ & $\begin{array}{l}\text { Southern California, } \\
\text { USA }\end{array}$ & Blake (1975) \\
\hline Early Miocene & $\begin{array}{l}\text { Mont Luberon, } \\
\text { France }\end{array}$ & $\begin{array}{l}\text { C. Meyer (pers. } \\
\text { comm.) }\end{array}$ \\
\hline $\begin{array}{l}\text { Late Eocene to } \\
\text { Early Miocene }\end{array}$ & $\begin{array}{l}\text { Santa Cruz Province, } \\
\text { Patagonia, Argentina }\end{array}$ & Caviglia (1976) \\
\hline Late Eocene & $\begin{array}{l}\text { Seymour Island, } \\
\text { Antarctica }\end{array}$ & $\begin{array}{l}\text { D. Blake (pers. } \\
\text { comm.) }\end{array}$ \\
\hline $\begin{array}{l}\text { Early Creta- } \\
\text { ceous }\end{array}$ & $\begin{array}{l}\text { Alexander Island, } \\
\text { Antarctica }\end{array}$ & Taylor (1966) \\
\hline Late Jurassic & Solnhofen, Germany & Kuhn (1963) \\
\hline Late Jurassic & Octeville, France & Meyer (1988) \\
\hline Late Jurassic & $\begin{array}{l}\text { Schofgraben, } \\
\text { Switzerland }\end{array}$ & Meyer (1984) \\
\hline Mid-Jurassic & $\begin{array}{l}\text { La Voulte-sur-Rhône, } \\
\text { France }\end{array}$ & $\begin{array}{l}\text { Dietl \& Mundlos } \\
\text { (1972) }\end{array}$ \\
\hline Mid-Jurassic & Weymouth, England & Hess (1964) \\
\hline Late Triassic & Allgäu, Germany & Meyer (1984) \\
\hline Mid-Triassic & $\begin{array}{l}\text { Nordwürttemberg, } \\
\text { Germany }\end{array}$ & Hagdorn (1985) \\
\hline Mid-Triassic & Roitzka, Poland & Kutscher (1940) \\
\hline Mid-Triassic & Weimar, Germany & Kutscher (1940) \\
\hline Mid-Triassic & $\begin{array}{l}\text { Mergentheim, } \\
\text { Germany }\end{array}$ & Kutscher (1940) \\
\hline Early Triassic & $\begin{array}{l}\text { West Dolomites, } \\
\text { Italy }\end{array}$ & $\begin{array}{l}\text { Longa \& } \\
\text { Cavacchi (1967) }\end{array}$ \\
\hline $\begin{array}{l}\text { Early Missis- } \\
\text { sippian }\end{array}$ & $\begin{array}{l}\text { Le Grand, lowa, } \\
\text { USA }\end{array}$ & $\begin{array}{l}\text { Laudon \& } \\
\text { Beane (1937) }\end{array}$ \\
\hline $\begin{array}{l}\text { Early Missis- } \\
\text { sippian }\end{array}$ & $\begin{array}{l}\text { Royalton, Ohio, } \\
\text { USA }\end{array}$ & $\begin{array}{l}\text { Kesling \& Le } \\
\text { Vasseur (1971) }\end{array}$ \\
\hline Late Devonian & Velbert, Germany & $\begin{array}{l}\text { Haude \& Thomas } \\
\text { (1983) }\end{array}$ \\
\hline Late Devonian & $\begin{array}{l}\text { Angerbachtal. } \\
\text { Germany }\end{array}$ & $\begin{array}{l}\text { Haude \& Thomas } \\
\text { (1983) }\end{array}$ \\
\hline Mid-Devonian & $\begin{array}{l}\text { Arkona, Ontario, } \\
\text { Canada }\end{array}$ & Keslıng (1969) \\
\hline Late Ordovician & $\begin{array}{l}\text { Waynesville, Ohio, } \\
\text { USA }\end{array}$ & Miljer (1882) \\
\hline Late Ordovician & $\begin{array}{l}\text { Franklin County, } \\
\text { Indiana, USA }\end{array}$ & $\begin{array}{l}\text { J. Pope (pers. } \\
\text { comm.) }\end{array}$ \\
\hline Late Ordovician & $\begin{array}{l}\text { Meaford, Ontario, } \\
\text { Canada }\end{array}$ & Foerste (1914) \\
\hline Mid-Ordovician & $\begin{array}{l}\text { Kirkfield, Ontario, } \\
\text { Canada }\end{array}$ & Liddell (1975) \\
\hline
\end{tabular}


Table 3. Proportion of individuals bearing 1 or more regenerating arms in dense, fossil ophiuroid populations

\begin{tabular}{|c|c|c|c|c|}
\hline \multirow{2}{*}{$\begin{array}{l}\text { Age } \\
\text { Pleistocene }\end{array}$} & Locality & \multicolumn{2}{|c|}{ Proportion injured (n) } & \multirow{2}{*}{$\begin{array}{l}\text { Source } \\
\text { This study }\end{array}$} \\
\hline & Chiba Prefecture, Japan & 0.00 & (29) & \\
\hline Late Miocene & Southern California, USA & 0.00 & (31) & This study \\
\hline Early to Mid-Miocene & Southern California, USA & 0.00 & (34) & This study \\
\hline Jurassic & Schofgraben, Switzerland & 0.0005 & $(\$ 100)$ & Meyer (1984) \\
\hline Jurassic & La Voulte-sur-Rhône, France & $<0.01$ & $(\geqslant 100)$ & Hess $(1960)$ \\
\hline Jurassic & Weymouth, England & 0.018 & (55) & Aronson \& Sues (1987) \\
\hline Mississippian & Le Grand, lowa, USA & 0.006 & $(160)$ & This study \\
\hline Mississippian & Royalton, Ohio, USA & 0.00 & $(200)$ & This study \\
\hline Ordovician & Waynesville, Ohio, USA & 0.00 & (21) & This study \\
\hline
\end{tabular}

dation, and the frequency of sublethal predation were all low in those ancient communities.

An alternative interpretation is that the frequency of predator-prey encounters was not low and that almost all attacks on ophiuroids were lethal (Schoener 1979, Vermeij 1982). However, all vertebrate and invertebrate predators of ophiuroids examined so far cause arm injuries (Aronson 1987). It is likely that functionally similar predators in the past also caused substantial sublethal damage.

Living brittlestar beds are subject to little predation, and injury levels are low. The even lower injury levels in fossil brittlestar beds indicate that some injury information is lost in the process of fossilization and/or that predation levels were lower in the ancient brittlestar beds. Post-mortem breakage can, in fact, reduce estimates of arm injury frequency in ophiuroids (Aronson 1991a). However, when injury values in fossil populations are near or equal to zero, it is doubtful that breakage has biased the estimates significantly; the number of injuries lost to the observer through taphonomic disarticulation declines as the estimate of proportion of individuals injured declines.

Therefore, ophiuroids in the 9 Paleozoic, Mesozoic, and Cenozoic fossil brittlestar beds apparently experienced low predation pressure. Generalizing from this sample of one-third of the known fossil populations, and from 6 living brittlestar beds (Sweetings Pond and 5 British beds; Aronson 1987, 1989a), the other fossil brittlestar beds probably also inhabited low-predation communities.

\section{Temporal distribution of fossil brittlestar beds}

The distribution of fossil brittlestar beds is examined quantitatively in Table 4. Observed frequencies in adjacent stratigraphic intervals are compared with the proportions expected if the assemblages were distributed randomly in time (see 'Appendix'). Analysis of this data base yields a general conclusion similar to that drawn by Aronson (1989b) with a smaller, geographically more restricted data base: brittlestar beds declined when functionally new predators radiated in the Mesozoic. However, while Aronson (1989b) argued that the decline occurred after the Jurassic, the expanded data base suggests an earlier decline. Onetailed binomial tests indicate a significant decline in the occurrence of brittlestar beds after the Triassic, but before the Cretaceous (Table 4A to F, Fig. 4).

The 3 largest Mesozoic extinction events occurred at the Permian-Triassic boundary, in the Late Triassic

Table 4. Binomial tests for declining occurrence of brittlestar beds in adjacent stratigraphic intervals

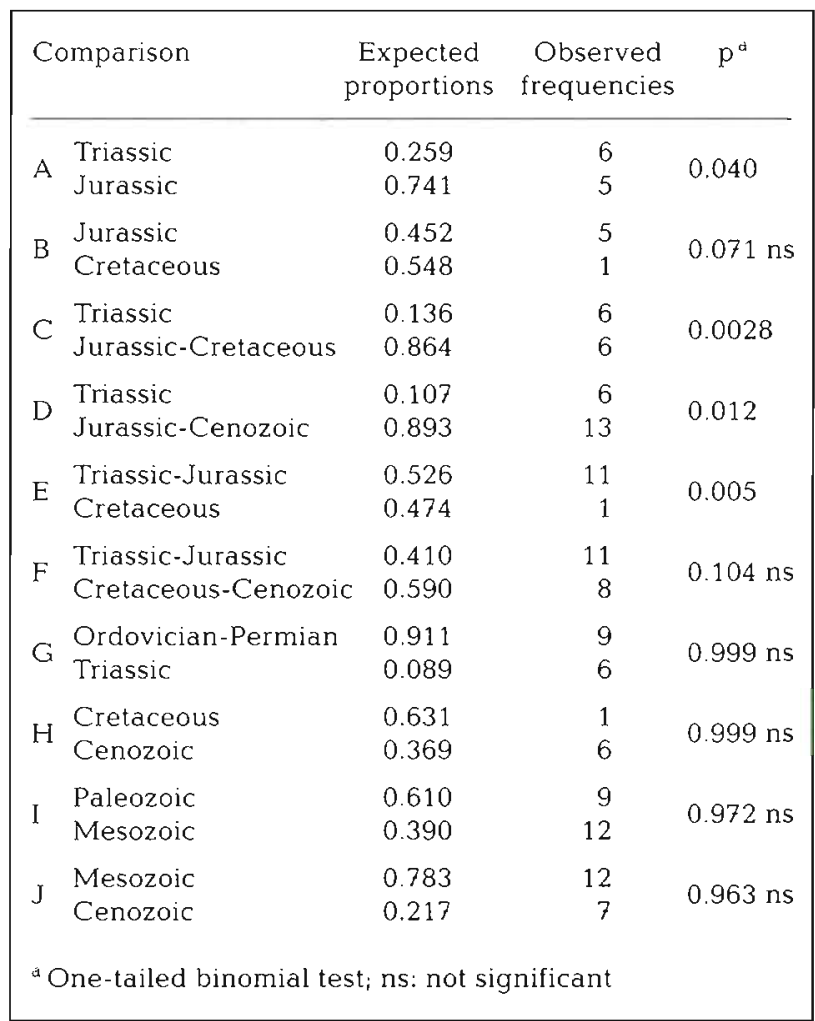




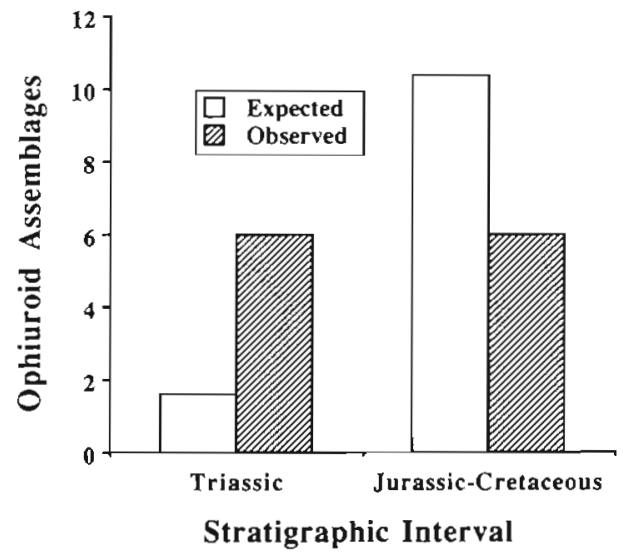

Fig. 4. Comparison of the expected and observed frequencies of occurrence of fossil brittlestar beds between the Triassic and the Jurassic-Cretaceous interval. Although the observed frequencies are equal, the expected frequency is considerably lower in the Triassic and considerably higher in the Jurassic-Cretaceous

(Norian stage), and at the Cretaceous-Tertiary boundary. Four minor extinction peaks took place in the Early and Late Jurassic (Pliensbachian and Tithonian), and during the Early and Late Cretaceous (Aptian and Cenomanian) (based on family-and genus-level analyses; Raup \& Sepkoski 1986, Sepkoski 1989). There is no evidence of a decline of brittlestar beds associated with the end-Permian or end-Cretaceous mass extinctions (Table $4 \mathrm{G}$ to $\mathrm{J}$ ). The remaining extinction candidates are the Norian, Pliensbachian, Tithonian, and Aptian extinctions. However, since ophiuroid familial and generic diversity increased during the Mesozoic (Spencer \& Wright 1966, Sepkoski 1982 and unpubl. update, 1991, Sepkoski unpubl. compendium of fossil marine genera), ophiuroid extinctions cannot account for the decline of brittlestar beds.

Brittlestar beds preserve in both carbonate and siliciclastic (terrigenous) sediments. There is no lithological reason why they should have declined after the Triassic (Aronson \& Sues 1987). On the other hand, the decline could have been due to increasing rates of bioturbation throughout the Mesozoic, particularly after the Triassic (Thayer 1983, Sepkoski et al. 1991). Bioturbators can have both ecological and taphonomic effects. They resuspend sediment, clogging the feeding apparatus of suspension-feeders and thereby restricting their distribution (the trophic amensalism hypothesis; Rhoads \& Young 1970). In addition, bioturbators can disrupt buried subfossil assemblages. Both of these processes would reduce the occurrence of fossil brittlestar beds, regardless of predation levels Bioturbation should not be excluded as a possible cause of the observed pattern, and it is likely that both predation and bioturbation were involved.
These results support the conclusion that, although ophiuroid species, genera, families, and orders evolved and went extinct over the course of the Phanerozoic mass extinctions were not directly responsible for the decline of brittlestar beds as a type of population in shallow water. Instead, the comparisons support the contention that brittlestar beds, like stalked crinoid assemblages and other communities of epifaunal suspension-feeders living on soft substrata, became restricted in their shallow-water distribution beginning in the Jurassic, when functionally new, durophagous predators, including teleosts, neoselachian sharks, and decapod crustaceans, began to diversify (Meyer \& Macurda 1977, Vermeij 1977, 1987, Thies \& Reif 1985). Those predator radiations, and the associated restriction of benthic communities, were well underway by the middle of the Cretaceous (above references, Oji 1985, Bottjer \& Jablonski 1988).

In summary, predation intensity within brittlestar beds remained low through the Mesozoic and into the Cenozoic. However, the evidence at hand suggests that the occurrence of those low-predation brittlestar beds declined markedly in the Jurassic, in association with the diversification of durophagous predators. The decline was not directly associated with the physical events that caused mass extinctions. Thus, predators affected brittlestar beds on an evolutionary scale in much the same way as they do on microecological and ecological scales of time and space.

\section{CONCLUSIONS}

As with all populations, the distribution of brittlestar beds is bounded by physical and physiological constraints. The regional and global limits to ophiuroid species' distributions are determined by their tolerances to salinity, temperature, and other physical factors. On a local level, although they can survive on a variety of substrata, the British brittlestar beds require sufficient energy input (usually via high water flow) to persist. They also require low rates of sedimentation: catastrophic sedimentation events are the very reason we have a fossil record of brittlestar beds. Ophiuroids in Sweetings Pond are limited by microtopography: they may require a heterogeneous substratum for efficient suspension-feeding.

Shallow areas of extreme wave energy no doubt prevent dense ophiuroid aggregations from forming. One might consider making a similar argument for exclusion from areas exposed to storms. Indeed, a lack of storm influence may be tautological on the microecological scale: the mere occurrence of a brittlestar bed excludes the possibility of its exclusion by storms at that particular time and place. However, there was 
no a priori reason to expect low-frequency, intense storms to be unimportant on the ecological scale, i.e. in the changes observed in the western English Channel after the late 1960s. Nor was there any reason to expect extremely low-frequency, extremely intense physical events - events that caused mass extinctions to have no direct effect on the evolutionary scale.

It is equally tempting to argue that the statement, 'Low predation pressure is a necessary condition for the persistence of brittlestar beds', begs the question. After all, how could predation possibly be significant in a habitat filled with prey? Yet low predation in brittlestar beds does not by itself explain the absence of dense populations from rocky reefs or coral reefs. There was certainly no a priori guarantee that predation would be far more intense in reef habitats than in brittlestar beds. As it happened, predatory fish and crabs were common in rocky reefs and uncommon or rare in British brittlestar beds. They were responsible for most of the attacks on tethered ophiuroids in the rocky reefs, whereas variations in Asterias rubens abundance had no appreciable effect on the mortality of tethered ophiuroids in brittlestar beds (Aronson 1989a).

Furthermore, dense ophiuroid populations are not simply saturating their predators, thereby lowering the per capita encounter rate. While a functional response argument cannot (and need not) be excluded, predation levels are not solely a consequence of relative abundance. Fish and crab abundance differed markedly between brittlestar beds and rocky reefs Another argument against predator satiation as the exclusive cause of low predation pressure is that predation pressure actually can be extremely high in one type of dense ophiuroid population. Dense populations of infaunal, suspension-feeding Amphiura filiformis in northern Europe persist under heavy predation pressure from flatfish; the proportion of ophiuroids regenerating arms in these populations is near unity (Bowmer \& Keegan 1983, Duineveld \& van Noort 1986). Hence, the mere occurrence of a dense population of ophiuroids does not necessarily imply low predation pressure in that habitat.

Neither biotic nor abiotic constraints are more important overall: they simply operate under different sets of circumstances (O'Neill et al. 1986). Where physical and energetic parameters permit brittlestar beds to occur, predation, rather than, say, a difference in larval supply, is a constraint of primary importance. As far as recruitment is concerned, it is presently untenable to argue on hydrodynamical grounds that sharp horizontal discontinuities in larval supply account for the absence of dense, exposed ophiuroid populations on rocky reefs and halos - habitats just meters away from where brittlestar beds begin abruptly. In any case, an argument for differential recruitment would still have to explain why there is no movement of adults from brittlestar beds to adjacent halo zones and rocky reefs.

In summary, the distribution of brittlestar beds in functionally appropriate environments, on multiple scales, is constrained by predation. Dense populations in Great Britain and the Bahamas can persist in the presence of slow-moving invertebrates - polychaetes, asteroids, and predatory ophiuroids - whose predatory capabilities evolved in the Paleozoic (Bambach 1985, Blake \& Guensberg 1988) or at the latest in the earliest Mesozoic (Gale 1987). However, modern brittlestar beds cannot persist in the presence of fish and crabs, just as the Mesozoic advent of durophagous teleosts and decapods severely limited brittlestar beds on the evolutionary scale.

Holme's (1984) data suggest that at least 1 genus of seastar can also limit modern brittlestar bed distribution, on a time scale of decades. Similar seastarophiuroid interactions may well have occurred at other times during the Phanerozoic. Seastar predation on ophiuroids does not alter the argument for fish and crab effects, for 2 reasons. First, on the evolutionary scale the global decline of brittlestar beds in the Mesozoic did not occur in conjunction with evolutionary innovations in seastar feeding mechanisms (Gale 1987, Blake \& Guensburg 1988). Second, the apparent ecological-scale effect of Luidia spp. on Ophiothrix fragilis beds was visible only because fish and crabs had not prevented those beds from persisting in a few restricted habitats. In other words, seastar predation further limits brittlestar beds, beyond the more fundamental limitation imposed by predatory fish and crabs.

\section{Thresholds and critical states}

Cracraft (1992) argued that a fundamental difficulty with theories of diversity-dependent diversification (e.g. Sepkoski 1984) is a lack of evidence that local, population-scale processes act at larger scales. Such evidence is now emerging from the fossil record (Sepkoski 1991). In the case of brittlestar beds, microecological-scale predator-prey interactions sum to produce analogous ecological- and evolutionaryscale interactions. Many complex factors determine the intensity of predation experienced by ophiuroids. At some point, predation intensity passes a threshold and brittlestar beds cannot persist. Threshold phenomena and alternate states are characteristic of both temperate and tropical communities (Sutherland 1974, 1981, Sebens 1986, Barkai \& McQuaid 1988, Aronson 1990, Knowlton in press), and Mann \& Lazier (1991) explicitly applied these concepts to the faunal changes associated with the Russell Cycle. For brittlestar beds, the thresholds, or critical states, arise weakly many times (habitat restriction on the microecological scale), 
more strongly fewer times (fluctuations in the English Channel on the ecological scale), and rarely with catastrophic intensity (evolutionary-scale restriction in the Mesozoic). Yet predation, one of several important limiting factors, has similar effects on vastly different spatial and temporal scales: the predator-ophiuroid interaction is scale-independent.

Self-similarity of pattern suggests that fractal processes may be operating. One possible explanation for the scale-independence seen in this biological interaction is self-organized criticality. As with sandpiles, earthquakes, and other self-critical systems, there is a limited range of scales over which predatorophiuroid trophodynamics are scale-invariant. The upper spatial limit is the size of the World Ocean, and the upper temporal limit is time from the Ordovician to the present. The lower spatiotemporal limits are scales below the level of the individual ophiuroid. The negative relationship observed between the frequency and magnitude of brittlestar bed exclusions may represent flicker noise, which is another characteristic of selforganized criticality.

Self-organized criticality may explain the Cambrian explosion (cf. McMenamin \& McMenamin 1990) and the history of mass extinctions (Plotnick \& Mckinney 1989, in press), and it may provide a theoretical framework for understanding punctuated evolutionary dynamics in general (Kauffman 1991, 1992). It may also account for the observed scaling of trophic interactions. Other biological interactions should be examined on ecological and evolutionary scales to test the applicability of self-organized criticality theory.

\section{APPENDIX}

\section{Expected values of occurrence of fossil assemblages}

In order to compare the occurrence of fossil brittlestar beds (or any other type of assemblage) between 2 stratigraphic intervals, it is necessary to account for several biases of the fossil record. These biases include the exponential decay of sedimentary rock over time, differences in the lengths of stratigraphic intervals, and changes in the area of epicontinental seas. Aronson (1989b) presented a 'life history' model to generate the ratio of assemblages expected in 2 stratigraphic intervals if those assemblages were distributed at random in the geological column. The model is reviewed here briefly.

The expected number $\left(N_{x}\right)$ of preserved communities from stratigraphic interval $x$ visible in the fossil record today is

$$
N_{x}=r^{\ell_{x}} \sum_{i=1}^{n_{x}} B_{x} r^{i}
$$

where $B_{x}=$ number of communities fossilized per million years; $r=$ probability that, once preserved, an assemblage will survive degradation to be present in the next millionyear interval; $n_{x}=$ length of the interval in millions of years; and $t_{x}=$ time elapsed between the end of the interval and the present, also in millions of years. During each million years of interval $x$, communities are fossilized and decay, and the decay continues from the end of the stratigraphic interval to the present.

$B_{x}$, the expected number of communities that become fossilized, depends on the area of the continents inundated by epicontinental seas, $A_{x}$. This may be expressed as

$$
B_{x}=A_{x} b
$$

where $b=$ number of communities buried and available for preservation per unit area of epicontinental sea per million years. The 'birth rate', $b$, is constant in the null hypothesis: we are using the null model to test for departures from a constant $b$
The expected ratio of the number of preserved assemblages in 2 stratigraphic intervals is

$$
N_{1} / N_{2}=A_{1} r^{i_{1}} \sum_{i=1}^{n_{1}} r^{\prime} / A_{2} r^{t_{2}} \sum_{i=1}^{n_{2}} r^{i}
$$

with $b$ canceling. Eq. (A3) reduces to

$$
N_{1} / N_{2}=r^{\left(i_{1}-t_{2}\right)}\left[A_{1}\left(1-r^{n_{1}}\right) / A_{2}\left(1-r^{n_{2}}\right)\right]
$$

and the proportion of assemblages that are from the first interval is $\left[\left(N_{1} / N_{2}\right) /\left(1+N_{1} / N_{2}\right)\right]$. If a stratigraphic interval spans more than 1 geological period, $N_{x}$ can be calculated for each period and then summed for the interval before dividing through in Eq. A4. The distribution of assemblages observed in the fossil record can then be compared statistically to the expected distribution using the binomial test, which is powerful even at low sample sizes (Siegel 1956). A continuous version of this model also yields Eq. A4

The per-million-year 'survivorship' of fossilized assemblages is estimated from the half-life of continental sedimentary rock, 375 million yr (Veizer \& Jansen 1985): the 375 th root of 0.5 gives $r=0.9982$. Average values of $A_{x}$ are taken from Sepkoski (1976; see Table 1 in Aronson $1989 \mathrm{~b})$, and the geological time scale used is that of Odin et al. (1982).

Paleontologists devote different amounts of research attention to different strata, and this may have introduced a monographic bias to the data compiled in Table 2 . However, Sheehan (1977) showed that, to a rough approximation, paleontological research interest declines with geological age in the same fashion as the amount of exposed sedimentary rock. Therefore, sampling from the literature and from personal communications probably gives a reasonably accurate picture of the temporal distribution of fossil brittlestar beds. 
Acknowledgements. I thank Daniel Blake, Jon Branstrator Rodney Feldmann, Gregg Gunnell, William Johnson, George Kennedy, David Lindberg. Christian Meyer, Sakae Ohara, Tatsuo Oji, John Pope, Michael Smith, and Jerome Thompson for access to fossil ophiuroids and for unpublished information on the localities of fossil brittlestar beds. David Meyer lent his expertise in facies interpretation, and J. J. Sepkoski Jr provided unpublished data on fossil ophiuroid families and genera. This paper benefited from discussions with Richard Bateman, Martin Buzas, James Cowen, William DiMichele, Ron Etter, Norman Holme (deceased), Fred Hotchkiss, David Pawson, Jan Witting, Lisa Young, and especially Roy Plotnick and Hans Sues. The comments of 3 anonymous reviewers are also appreciated. Research in Japan was supported by the Smithsonian Institution Scholarly Studies Program.

\section{LITERATURE CITED}

Allen, P. M. (1985). Ecology, thermodynamics, and selforganization: towards a new understanding of complexity In: Ulanowicz, R. E., Platt, T (eds.) Ecosystem theory for biological oceanography. Can. Bull. Fish. Aquat. Sci. 213 $3-26$

Allen, T. F. H., Starr, T. B. (1982). Hierarchy: perspectives for ecological complexity. University of Chicago Press, Chicago

Allman (1863). On a new fossil Ophiuridan, from postPliocene strata of the Valley of the Forth. Proc. R. Soc Edinburgh 5: 101-104

Alva, $V_{\text {., Jangoux, M. (1990). Fréquence et causes presumées }}$ de la régénération brachiale chez Amphipholis squamata (Echinodermata: Ophiuroidea). In: De Ridder, C., Dubois, P., Lahaye, M.-C., Jangoux, M. (eds.) Echinoderm research: Proceedings of the Second European Conference on Echinoderms. A. A. Balkema, Rotterdam, p. 147-153

Anonymous (1960-75). The annual summary of the monthly weather report for 19XX. Her Majesty's Stationery Office, London

Appleton, R. D., Palmer, A. R. (1988). Water-borne stimuli released by predatory crabs and damaged prey induce more predator-resistant shells in a marine gastropod. Proc. natl Acad. Sci. U.S.A. 85: $4387-4391$

Aronson, R. B. (1987). Predation on fossil and Recent ophiuroids. Paleobiology 13: 187-192

Aronson, R. B. (1989a). Brittlestar beds: low-predation anachronisms in the British Isles. Ecology 70: 856-865

Aronson, R. B. (1989b). A community-level test of the Mesozoic marine revolution theory. Paleobiology 15: $20-25$

Aronson, R. B. (1990). Onshore-offshore patterns of human fishing activity. Palaios 5: 88-93

Aronson, R. B. (1991a). Predation, physical disturbance, and sublethal arm damage in ophiuroids: a Jurassic-Recent comparison. Mar. Ecol. Prog. Ser. 74: 91-97

Aronson, R. B. (1991b). Hurricane effects on Caribbean echinoderm faunas: preliminary results (abstract). In: Yanagisawa, T., Yasumasu, I., Oguro, C., Suzuki, N., Motokawa, $T$ (eds.) Advances in echinoderm biology: proceedings of the Seventh International Echinoderm Conference, Japan. A. A. Balkema, Rotterdam, p. 143

Aronson, R. B. (in press). The effects of geography and hurricane disturbance on a tropical predator-prey interaction J. exp. mar. Biol. Ecol

Aronson, R. B., Harms, C. A. (1985). Ophiuroids in a Bahamian saltwater lake: the ecology of a Paleozoic-like community. Ecology 66: 1472-1483
Aronson, R. B. Sues, H.-D. (1987). The paleoecological significance of an anachronistic ophiuroid community. In Kerfoot, W. C., Sih, A. (eds.) Predation: direct and indirect impacts on aquatic communities. University Press of New England, Hanover, p. 355-366

Bak, P., Chen, K. (1989). The physics of fractals. Physica D 38 $5-12$

Bak, P., Chen, K. (1991). Self-organized criticality. Scient. Am 264(1): 46-53

Bailey, R. H. (1990). Significance of hierarchical structure and scale in stratigraphy and paleoecology: an example from the Pliocene of North Carolina. In: Miller, W. III led.) Paleocommunity temporal dynamics: the long-term development of multispecies assemblies. Paleont. Soc. Spec Pub. No. 5, University of Tennessee, Knoxville, p. 236-261

Bambach, R. K. (1985). Classes and adaptive variety; the ecology of diversification in marine faunas through the Phanerozoic. In: Valentine, J. W. (ed.) Phanerozoic diversity patterns: profiles in macroevolution. Princeton University Press, Princeton, p. 191-253

Barkai, A., McQuaid, C. (1988). Predator-prey role reversal in a marine benthic ecosystem. Science 242: 62-64

Blake, D. B. (1975). A new west American Miocene species of the modern Australian ophiuroid Ophiocrosscta. J. Paleontol. 49: 501-507

Blake, D. B., Guensburg. T. E. (1988). The water vascular system and functional morphology of Paleozoic asteroids. Lethaia 21: 189-206

Bottjer, D. J., Jablonski, D. (1988). Paleoenvironmental patterns in the evolution of post-Paleozoic benthic marine invertebrates. Palaios 3: 540-560

Bowmer, T., Keegan, B. F. (1983). Field survey of the occurrence and significance of regeneration in Amphiura filiformis (Echinodermata: Ophiuroidea) from Galway Bay, west coast of Ireland. Mar. Biol. 74: 65-71

Brun, E. (1972). Food and feeding habits of Luidia ciliaris (Echinodermata: Asteroidea). J. mar. biol. Ass. U.K. 52 225-236

Carpenter, S. R., Leavitt, P. R. (1991). Temporal variation in a paleolimnological record arising from a trophic cascade. Ecology 72: 277-285

Caviglia, S. E. (1976). Presencia del genero Ophiocrossota (Echinodermata, Ophiurida, Ophiuridae) en el Terciario marino de Patagonia. Ameghiniana 13: 331-332

Chadwick, H. C. (1886). Report on the Ophiuroidea of the L.M.B.C. district. In: Herdman, W. A. (ed.) The first report upon the fauna of Liverpool Bay and the neighbouring seas. Longmans, Green, London, p. 140-143

Cracraft, J. (1992). Explaining patterns of biological diversity: integrating causation at different spatial and temporal scales. In: Eldredge, N. (ed.) Systematics, ecology, and the biodiversity crisis. Columbia University Press, New York, p. $59-76$

Dietl, G., Mundlos, R. (1972). Ökologie und Biostratinomie von Ophiopinna elegans aus dem Untercallovium von La Voulte (Südfrankreich). Neues Jb. Geol. Paläont. Mh. 1972: $449-464$

Draper, L. (1967). Wave activity at the sea bed around northwestern Europe. Mar. Geol. 5: 133-140

Duineveld, G. C. A., Künitzer, A., Niermann, U., de Wilde, P. A. W. J., Gray, J. S. (1991). The macrobenthos of the North Sea. Neth. J. Sea Res. 28: 53-65

Duineveld, G. C. A., van Noort, G. J. (1986). Observations on the population dynamics of Amphiura filiformis (Ophiuroidea: Echinodermata) in the southern North Sea and its exploitation by the dab, Limanda Limanda. Neth. J. Sea Res. 20: 85-94 
Eldredge, N. (1989). Macroevolutionary dynamics: species, niches, and adaptive peaks. McGraw-Hill, New York

Fenchel, T. (1965). Feeding biology of the sea-star Luidia sarsi Düben \& Koren. Ophelia 2: 223-236

Flam, F. (1991). Beating a fractal drum. Science 254: 1593

Foerste, A. F. (1914). Notes on the Lorraine faunas of New York and the province of Quebec. Bull. Sci. Labs. Denison Univ. 17: 247-339

Frost, T M., DeAngelis, D. L., Bartell, S. M., Hall, D. J., Hurlbert, S. M. (1988). Scale in the design and interpretation of aquatic community research. In: Carpenter, S. R. (ed.) Complex interactions in lake communities. SpringerVerlag, New York, p. 229-258

Gale, A. S. (1987). Phylogeny and classification of the Asteroidea (Echinodermata). Zool. J. Linn. Soc. 89: 107-132

Gingerich, P. D. (1983). Rates of evolution: effects of time and temporal scaling. Science 222: 159-161

Gleick, J. (1987). Chaos: making a new science. Penguin Books, New York

Goldring, R., Stephenson, D. G. (1972). The depositional environment of three starfish beds. Neues Jb. Geol. Paläont. Mh. 1972: 611-624

Gould, S. J. (1985). The paradox of the first tier: an agenda for paleobiology. Paleobiology 11:2-12

Hagdorn, H. (1985). Seestern- und Schlangenstern-Lager im Muschelkalk. Fossilien 2: 83-87

Hay, M. E. (1984). Patterns of fish and urchin grazing on Caribbean coral reefs: are previous results typical? Ecology 65: $591-598$

Haude, R., Thomas, E. (1983). Ophiuren (Echinodermata) des hohen Oberdevon im nördlichen Rheinischen Schiefergeberge. Paläont. Z. 57: 121-142

Hess, H. (1960). Neubeschreibung von Geocoma elegans (Ophiuroidea) aus dem unteren Callovien von La Voultesur-Rhône (Ardèche). Eclog. geol. Helv. 53: 335-385

Hess, H. (1964). Die Ophiuren des englischen Jura. Eclog. geol. Helv. 57: 755-802

Hily, C. (1991). Is the activity of benthic suspension feeders a factor controlling water quality in the Bay of Brest? Mar. Ecol. Prog. Ser. 69: 179-188

Hily, C., Girardeau, J.-P., Quéquiner, B. (1988). Rythme tidal d'activité trophique d'Ophiothrix fragilis en rade de Brest. C. r. Acad Sci. Paris, Sér. III 307: 265-270

Holme, N. A. (1984). Fluctuations of Ophiothrix fragilis in the western English Channel. J. mar. biol. Ass. U.K. 64: $351-378$

Jablonski, D. (1986). Background and mass extinctions: the alternation of macroevolutionary regimes. Science 231: $129-133$

Jackson, J. B. C. (1991). Adaptation and diversity of reef corals. BioSci. 41: 475-482

Kauffman, S. A. (1991). Antichaos and adaptation. Scient. Am. 265(2): $78-84$

Kauffman, S. A. (1992). The origins of order: self-organization and selection in evolution. Oxford University Press, New York

Kesling, R. V (1969). A new brittle-star from the Middle Devonian Arkona Shale of Ontario. Contrib. Mus. Paleont. Univ. Mich. 23: 37-51

Kesling, R. V., Le Vasseur, D. (1971). Strataster ohioensis, a new Early Mississippian brittle-star, and the paleoecology of its community. Contrib. Mus. Paleont. Univ. Mich. 23: $305-341$

Knowlton, N. (in press). Thresholds and multiple stable states in coral reef community dynamics. Am. Zool.

Kuhn, O. (1963). Die Tierwelt des Solnhofener Schiefers
Ziemsen, Wittenberg-Lutherstadt

Kutscher, F. (1940). Ophiuren-Vorkommen im Muschelkalk Deutschlands. Z. dt. geol. Ges. 92: 1-18

Laudon, L. R., Beane, B. H. (1937). The crinoid fauna of the Hampton Formation at Le Grand, lowa. Univ. Iowa Stud nat. Hist. $27: 227-272$

Liddell, W. D. (1975). Ecology and biostratinomy of a Middle Ordovician echinoderm assemblage from Kirkfield Ontario. M.A. thesis, University of Michigan, Ann Arbor

Lidgard, S. (1986). Ontogeny in animal colonies: a persistent trend in the bryozoan fossil record. Science 232: 230-232

Lidgard, S., Jackson, J. B. C. (1989). Growth in encrusting cheilostome bryozoans: I. Evolutionary trends. Paleobiology 15: 255-282

Loriga, C. B., Cavacchi, A. (1967). Eccezionale reperto di un gruppo di ofiuroidi nel Werfeniano delle Dolomiti Occidentali (Gruppo della Costabella). Lincel - Rend. Cl. Sc. Fis. Mat. e Nat. (Serie 8) 43: 91-95

Mandelbrot, B. B. (1983). The fractal geometry of Nature. W. H. Freeman \& Company, San Francisco

Mandelbrot, B. B. (1989). Fractal geometry: what is it, and what does it do? Proc. R. Soc. Lond. 423: 3-16

Mann, K. H., Lazier, J. R. N. (1991). Dynamics of marine ecosystems. Blackwell Scientific Publications, Boston

McMenamin, M. A. S., McMenamin, D. L. S. (1990). The emergence of animals: the Cambrian breakthrough Columbia University Press, New York

Mehta, A., Barker, G. (1991). The self-organising sandpile. New. Scient. 130(1773): 40-43

Menge, B. A., Olson, A. M. (1990). Role of scale and environmental factors in regulation of community structure. Trends Ecol. Evol. (TREE) 5: 52-57

Merriam, C. W. (1931). Notes on a brittle-star limestone from the Miocene of California. Am. J. Sci. (Ser. 5) 21:304-310

Meyer, C. A. (1984). Palökologie und Sedimentologie der Echinodermenlagerstätte Schofgraben (mittleres Oxfordian, Weissenstein, Kt. Solothurn). Eclog. geol. Helv. 77: $649-673$

Meyer, C. A. (1988). Paléoécologie d'une communauté d'ophiures du Kimméridgien supérieur de la région Havraise (Seine Maritime). Bull. Trim. Soc. Géol. Normandie et Amis Museum du Havre 75: 25-35

Meyer, D. L., Macurda, D. B. Jr (1977). Adaptive radiation of the comatulid crinoids. Paleobiology 3: 74-82

Miller, S. A. (1882). Description of two new genera and eight new species of fossils from the Hudson River group, with remarks upon others. J. Cincinnati Soc. nat. Hist. 5: 34-44

Montgomery, D. R., Dietrich, W. E. (1992). Channel initiation and the problem of landscape scale. Science 255: 826-830

Muus, K. (1981). Density and growth of juvenile Amphiura filiformis (Ophiuroidea) in the Øresund. Ophelia 20: 153-168

Odin, G. S., Curry, D., Gale, N. H., Kennedy, W. J. (1982). The Phanerozoic time scale in 1981 in: Odin, G. S. (ed.) Numerical dating in stratigraphy. John Wiley \& Sons, Chichester, p. 957-960

Oji, T (1985). Early Cretaceous Isocrinus from northeast Japan. Palaeontology 28: 629-642

O'Neill, R. V., DeAngelis, D. L., Waide, J. B., Allen, T F. H. (1986). A hierarchical concept of ecosystems. Princeton University Press, Princeton

Palmer, M. W. (1992). The coexistence of species in fractal landscapes. Am. Nat. 139: 375-397

Pimm, S. L. (1991). The balance of nature? University of Chicago Press, Chicago

Plotnick, R. E., McKinney, M. L. (1989). Ecosystem dynamics and periodic extinctions. Geol. Soc. Am. Abst. Prog. 21. A207-A208 
Plotnick, R. E., McKinney, M. L. (in press). Ecosystem organization and extinction dynamics. Palaios

Powell, T M. (1989). Physical and biological scales of variability in lakes, estuaries, and the coastal ocean. In Roughgarden, J., May, R. M., Levin, S. A. (eds.) Perspectives in ecological theory. Princeton University Press, Princeton, p. 157-176

Raup, D. M., Sepkoski, J. J. Jr (1986). Periodic extinction of families and genera. Science 231: 833-836

Rhoads, D. C., Young, D. K. (1970). The influence of depositfeeding organisms on sediment stability and community trophic structure. J. mar. Res. 28: 150-178

Rosenkranz, D. (1971). Zur Sedimentologie und Ökologie von Echinodermen-Lagerstätten. Neues Jb. Geol. Paläont. A.bh. 138: 221-258

Sale, P. F. (1980). The ecology of fishes on coral reefs Oceanogr. mar. biol. A. Rev. 18: 367-421

Schäfer, W. (1962). Aktuopaläontologie nach Studien in der Nordsee. W. Kramer, Frankfurt

Schoener, T W. (1979). Inferring the properties of predation and other injury-producing agents from injury frequen. cies. Ecology 60: 1110-1115

Sebens, K. P. (1986). Community ecology of vertical walls in the Gulf of Maine, USA: small scale processes and alternative community states. In: Moore, P. G., Seed, R. (eds.) The ecology of rocky coasts. Hodder and Stoughton, London, p. 346-371

Seeley, R. F. (1986). Intense natural selection caused a rapid morphological transition in a living marine snail. Proc. nat Acad. Sci. U.S.A. 83: 6897-6901

Sepkoski, J. J. Jr (1976). Species diversity in the Phanerozoic: species-area effects. Paleobiology 2: 298-303

Sepkoski, J. J. Jr (1982). A compendium of fossil marine families. Milwaukee Public Mus. Contr. Biol. Geol. 51. 1-125

Sepkoski, J. J. Jr (1984). A kinetic model of Phanerozoic taxonomic diversity. IV. Post-Paleozoic families and mass extinctions. Paleobiology 10: 246-267

Sepkoski, J. J. Jr (1989). Periodicity of extinction and the problem of catastrophism in the history of life. J. geol. Soc. Lond. 146: 7-19

Sepkoski, J. J. Jr (1991). Diversity in the Phanerozoic oceans: a partisan view. In: Dudley, E. C. (ed.) The unity of evolutionary biology: Proceedings of the Fourth International Congress of Systematic and Evolutionary Biology, Vol. 1. Dioscorides Press, Portland, p. 210-236

Sepkoski, J. J. Jr, Bambach, R. K., Droser, M. L. (1991). Secular changes in Phanerozoic event bedding and the biological overprint. In: Einsele, G., Ricken, W., Seilacher, A. (eds.) Cycles and events in stratigraphy. Springer-Verlag, New York, p. 298-312

Sheehan, P. M. (1977). Species diversity in the Phanerozoic: a reflection of labor by systematists? Paleobiology 3: $325-329$

Siegel, S. (1956). Nonparametric statistics for the behavioral sciences. McGraw-Hill, New York

Sollins, P., Spycher, G., Topik, C. (1983). Processes of soil organic-matter accretion at a mudflow chronosequence, Mount Shasta, California. Ecology 64: 1273-1282

Southward, A. J. (1980). The western English Channel - an inconstant ecosystem? Nature 285: 361-366
Spencer, W. K., Wright, C. W. (1966). Asterozoans. In: Moore R. C. (ed.) Treatise on invertebrate paleontology, Part U: Echinodermata 3, Vol. 1 University of Kansas Press Lawrence, p. U4 - U107

Steele, J H. (1985). A comparison of terrestrial and marine ecological systems. Nature 313: 355-358

Steneck, R. S. (1983). Escalating herbivory and resulting adaptive trends in calcareous algal crusts. Paleobiology 9 $44-61$

Sugihara, G., May, R. M. (1990). Applications of fractals in ecology. Trends Ecol. Evol. (TREE) 5: 79-86

Sutherland, J. P. (1974). Multiple stable points in natural communities. Am. Nat. 108: 859-873

Sutherland, J. P. (1981). The fouling community at Beaufort, North Carolina: a study in stability. Am. Nat. 118 $499-519$

Taylor, B. J. (1966). Taxonomy and morphology of Echinodermata from the Aptian of Alexander Island. Br Antarct. Surv. Bull. 8: 1-18

Thayer, C. W. (1983). Sediment-mediated biological disturbance and the evolution of marine benthos. In: Tevesz, M J. S., McCall, P. L. (eds.) Biotic interactions in Recent and fossil benthic communities. Plenum Press, New York, p. $479-625$

Thies, D., Reif, W.-E. (1985). Phylogeny and evolutionary ecology of Mesozoic Neoselachii. Neues Jb. Geol. Paläont. Abh. 169: 333-361

Veizer, J., Jansen, S. L. (1985). Basement and sedimentary recycling -2 : Time dimension to global tectonics. J. Geol. 3 : $625-643$

Vermeij, G. J. (1977). The Mesozoic marine revolution: evidence from snails, predators and grazers. Paleobiology 3 $245-258$

Vermeij, G. J. (1978). Biogeography and adaptation: patterns of marine life. Harvard University Press, Cambridge, MA

Vermeij, G. J. (1982). Unsuccessful predation and evolution. Am. Nat. 120: 701-720

Vermeij, G. J. (1987). Evolution and escalation: an ecological history of life. Princeton University Press, Princeton

Victor, B. C. (1986). Larval settlement and juvenile mortality in a recruitment-limited coral reef fish population. Ecol. Monogr. 56: 145-160

Warner, G. F. (1971). On the ecology of a dense bed of the brittle-star Ophiothrix fragilis. J. mar biol. Ass. U.K. 51 $267-282$

Warner, G. F. (1982). Food and feeding mechanisms Ophiuroidea. In: Jangoux, M., Lawrence, J. M. (eds.) Echinoderm nutrition. A. A. Balkema, Rotterdam, p. $161-181$

Warner, G. F., Woodley, J. D. (1975). Suspension-feeding in the brittle-star Ophiothrix fragilis. J. mar. biol. Ass. U.K. 55: $199-210$

West, K., Cohen, A., Baron, M. (1991). Morphology and behavior of crabs and gastropods from Lake Tanganyika, Africa: implications for lacustrine predator-prey coevolution. Evolution 45: 589-607

Wiens, J. A. (1989). Spatial scaling in ecology. Funct. Ecol. 3: 385-397

Woodley, J. D., and co-authors (1981). Hurricane Allen's impact on Jamaican coral reefs. Science 214: 749-755

Manuscript first received: January 30, 1992

Revised version accepted: October 5, 1992
This article was presented by J. M. Lawrence, Tampa,

Florida, USA 